\title{
Beneficial reuse: A field trial to remediate and a bench-scale test to revegetate coal seam gas dam sediments from Queensland
}

\author{
Lee Fergusson \\ Principal Consultant, Prana World Consulting, Gold Coast, Australia
}

\section{Email address:}

lee@pranaworldgroup.com

\section{To cite this article:}

Lee Fergusson. Beneficial Reuse: A Field Trial to Remediate and a Bench-Scale Test to Revegetate Coal Seam Gas Dam Sediments from Queensland. American Journal of Environmental Protection. Vol. 3, No. 5, 2014, pp. 249-257. doi: 10.11648/j.ajep.20140305.17

\begin{abstract}
Coal seam gas (CSG) has become an increasingly common method of extracting methane from coal in Australia, with more than 20,000 wells expected to enter production by 2020 . However, large quantities of "produced water" also come to the surface with gas, and these several thousand litres of water per day per well have to be managed sustainably. Furthermore, up to five percent of produced water is composed of suspended or dissolved solids, most typically present in the form of salty brines and a range of other elements, sometimes including benzene and other hydrocarbons like phenols. CSG solids therefore have a high $\mathrm{pH}$ and total alkalinity, and hence have elevated electrical conductivity. As a consequence, the settled solids from CSG extraction have no proven beneficial reuse value, and successful revegetation of dams and untreated sediments is limited to salt-tolerant grass species but is often impossible using any species under any condition. The purpose of this study is to investigate the remediation of CSG dam sediments from Queensland for the purposes of determining their potential beneficial reuse as "clean, usable soil" in revegetation projects. Experiment \#1, a field trial conducted in the Bowen Basin, examined the impact of various additives to two different types of CSG dam sediments. Experiment \#1 found that both types of sediment could be remediated, examples of which include decreases in $\mathrm{pH}$ from 10.0 to 7.4 , chloride from $19,900 \mathrm{mg} / \mathrm{kg}$ to $1,770 \mathrm{mg} / \mathrm{kg}$, cation-exchange capacity (CEC) from $23 \mathrm{meq} / 100 \mathrm{~g}$ to $4.0 \mathrm{meq} / 100 \mathrm{~g}$, and sodium adsorption ratio (SAR) from $931 \mathrm{meq} / 100 \mathrm{~g}$ to $44 \mathrm{meq} / 100 \mathrm{~g}$, and increases in total phosphorus from $27 \mathrm{mg} / \mathrm{kg}$ to $855 \mathrm{mg} / \mathrm{kg}$ and total nitrogen from $950 \mathrm{mg} / \mathrm{kg}$ to $3,520 \mathrm{mg} / \mathrm{kg}$. These findings confirm that contaminated CSG sediments have beneficial reuse potential in dam decommissioning and revegetation projects. Experiment \#2, a bench-scale test utilizing samples of treated sediments from Experiment \#1, examined the revegetation potential of these remediated CSG sediments. Experiment \#2 showed that both types of CSG dam sediment could be effectively revegetated using non-salt-tolerant grass species, while untreated sediments were not suitable for revegetation. However, the design and scale of this work need to be expanded, and variables such as sediment $\mathrm{pH}$, CEC and SAR should be monitored and controlled more carefully before fully reliable conclusions can be made about the revegetation potential of treated CSG dam sediments.
\end{abstract}

Keywords: Beneficial Reuse, Coal Seam Gas, CSG, Sediments, Remediation, Revegetation

\section{Introduction}

At the turn of the last century, a significant shortfall in natural gas supplies was forecast for Australia, with the predicted shortage to be made up by gas piped to the mainland across Torres Strait from Papua New Guinea (PNG) in the north and from the gas fields of Bass Strait in the south [1]. Greater industrial and regulatory focus, particularly in the states of Queensland and New South Wales, was therefore placed on the development of indigenous, unconventional gas resources on the Australian mainland, with coal seam gas (CSG) extraction finding particular favor. As a consequence, the need for importing gas from PNG and Bass Strait has been obviated in the last ten years, and no shortfalls are now predicted [2].

In fact, the primary sedimentary coal basins in eastern Australia have now proven and probable reserves of natural gas derived from CSG totaling 28,000 pentajoules (PJ), 
representing more than $60 \%$ of the known gas reserves [1]. To put this figure into context, total Australian natural gas reserves were 5PJ in 1996, with CSG production increasing from 1PJ per annum in 1996 to $167 \mathrm{PJ}$ per annum by 2008 to a further 264PJ per annum by 2013 [3].

The "natural gas" referred to in these figures is comprised of two basic types of CSG: "dry gas", which is composed of $>95 \%$ methane $\left(\mathrm{CH}_{4}\right)$; and "wet gas", which is composed of $<95 \%$ methane. Both dry and wet gas contain varying amounts of ethane $\left(\mathrm{C}_{2} \mathrm{H}_{6}\right)$, propane $\left(\mathrm{C}_{3} \mathrm{H}_{8}\right)$, and butane $\left(\mathrm{C}_{4} \mathrm{H}_{10}\right)$, along with other secondary gases, including carbon dioxide $\left(\mathrm{CO}_{2}\right)$, hydrogen sulfide $\left(\mathrm{H}_{2} \mathrm{~S}\right)$, hydrogen $(\mathrm{H})$, nitrogen $(\mathrm{N})$, helium (He), and argon (Ar). Perhaps more importantly for the Australian economy, the rapid expansion of CSG production has resulted in not only the obviation of gas imports but a net gain in gas production levels, generating an entirely new economic opportunity for the export of liquefied natural gas (LNG) from Australia to markets in Asia, with multi-billion dollar gas export terminals and rail infrastructure being built throughout Queensland.

These growth trends are not dissimilar to the growth trends in the natural gas economy of the U.S. currently being driven by shale oil gas from which much of the Australian experience has been derived.

The presence and potential build-up of methane in underground coal mines has been well documented in Australia for over 100 years; however, methane was typically extracted and flared prior to coal being mined safely rather than being used as a fuel source. It was not until the late 1930s that CSG was first recognized as a resource in its own right, being commercially produced at an abandoned colliery in New South Wales during the Second World War [4].

Given that gas extracted by "unconventional" methods like CSG typically resides as much shallower depths than "conventional" natural gas reserves (i.e., generally $<1,000 \mathrm{~m}$ below the surface, in layers or seams ranging in thicknesses from a few millimetres to tens of metres), its commercial potential has been well understood since the mid-twentieth century, but it has taken technological developments in geology, engineering, and chemistry 60 years to fully realize this potential.

In Queensland, 50 significant gas fields have been identified, including the smaller Styx Basin, the Laura Basin and the Cooper Basin, with the Bowen Basin (including the Bandanna, Baralaba, and Mornabah Coal Measures), the Surat Basin (including the Walloon Coal Measure), and the Galilee Basin (predicted to be one of the largest coal basins in the world, including the Betts Creek and Aramac Coal Measures) among the most productive or potentially productive fields in the State [4, 5]. For example, declared in June, 2014 by the Queensland Government, the so-called Galilee Basin State Development Area has been created to support the development of coal and gas reserves of the Galilee Basin, with an estimated $\$ 28$ billion investment in infrastructure expected over the next ten years, including a new airport, rail corridors and export hub at Abbot Point.

Both CSG and conventional gas originate as decomposing organic matter in coal as a result of thermogenic and biogenic processes. However, where conventional gas migrates through permeable rock and eventually lodges in stratigraphic layers (usually at depths $>1,000 \mathrm{~m}$ ), CSG adsorbs into the coal matrix and is held in place by fluid pressure, thereby making it less economic to extract when compared to conventional gas. This so-called "unminable gas" can be effectively liberated from coal using either CSG extraction processes, including hydraulic rock fracturing (or "fracking", where a variety of polymer-based foaming gels, liquids and gases are used as fracturing fluids), or by underground coal gasification (UCG).

Whereas UCG utilizes combustion of gas at high temperature to produce synthetic gas or "syngas" (i.e., a combination of mostly carbon monoxide [CO], hydrogen $[\mathrm{H}]$, and carbon dioxide $\left[\mathrm{CO}_{2}\right]$ ), $\mathrm{CSG}$ liberates methane through the depressurization of coal seams by either removing (when gas resides in aquifers) or injecting (when the seam is dry) fresh or treated water. As a consequence, CSG processes generate large quantities of so-called "produced water" in addition to gas, and this water, often contaminated with phenols, heavy metals (including lead, mercury and arsenic [6]), benzene, and other organic and inorganic contaminants, including ions like sodium and chloride [7, 8], must be managed sustainably.

For example, an average CSG well in Queensland generates between 3,000 litres and several hundred thousand litres of produced water per day, depending on the type of seam formation [9]. With about 4,000 CSG wells in operation throughout the State, a total of $16.9 \mathrm{GL}$ of produced water was generated in 2012-2013 [3].

However, given that the number of CSG wells in production is projected to reach $20,000-40,000$ by 2020 [8], the volume of wastewater generated the industry may reach more than 100GL per year within six years.
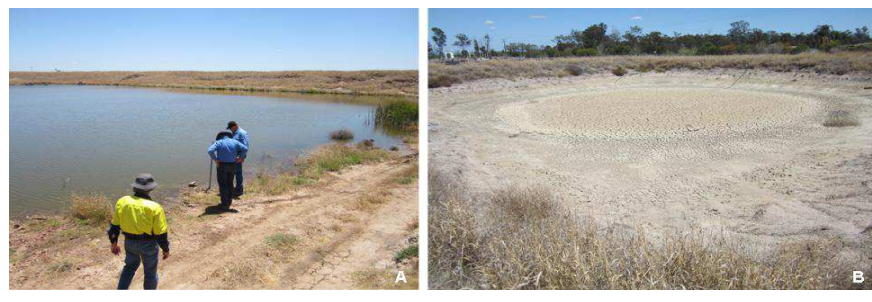

Figure 1. Photographic examples of an operating CSG dam (A) and a dam after evaporation of produced water $(B)$ in the Bowen Basin in central Queensland, 2013.

CSG produced water is stored in open evaporation dams, such as those shown in Figures 1 and 2. These dams, sometimes called "turkey's nests" because they are strung together to form large overflowing evaporative pans, can be up to 100ha in size and may contain several gigalitres of produced water, most of it in a moderate to acute saline state when measured by total dissolved solids (TDS). The TDS of CSG produced water is normally between a few hundred parts per million and $10,000 \mathrm{mg} / \mathrm{L}$, composed mainly of sodium $(\mathrm{Na})$, chloride $(\mathrm{Cl})$, and potassium $(\mathrm{K})$. To put these levels of salinity into context, standard drinking water contains $<500 \mathrm{mg} / \mathrm{L}$ TDS and global seawater averages are $35,000 \mathrm{mg} / \mathrm{L}$ TDS, with the majority of 
salinity originating from sodium $(\mathrm{Na})$, chloride $(\mathrm{Cl})$, magnesium $(\mathrm{Mg})$, calcium $(\mathrm{Ca})$, potassium $(\mathrm{K})$, and sulfate $\left(\mathrm{SO}_{4}\right)$.

Moreover, about 3-5\% of CSG produced water by volume is actually a solid, typically present as suspended, colloidal particles or as dissolved solids. Most of the colloidal solids are composed of indigenous alkanic hydrocarbons or clay particles, and most of the dissolved solids are so-called "salty brines", which do not form part of the gas fraction and must be partitioned after the gas-water mix is brought to the surface. As a consequence, high levels of sodium, chloride, potassium and other ions accumulate in the evaporation dams as a dense brine, because these "salts" are concentrated in dams when water evaporates.

The standard design of CSG dams means that produced water either evaporates, is recycled as stock drinking water, irrigation water, or cooling water after treatment with reverse osmosis (RO), or is disposed as "trade waste" to a wastewater or sewage treatment plant [10]. Supplementing potable water with treated produced water has been considered, but the concept has not gained regulatory or public approval due to the fact that low weight molecules and uncharged organic chemicals may be rejected by RO membranes, thereby potentially entering the water supply chain [6].
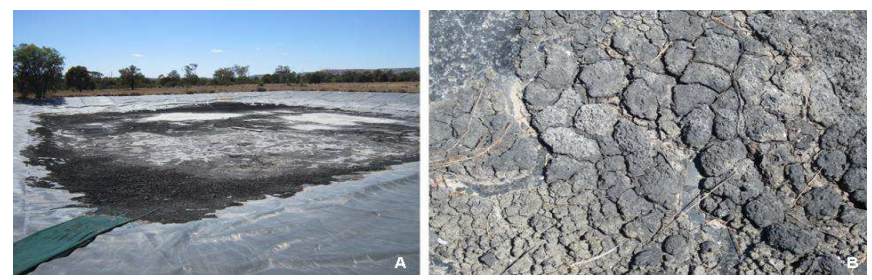

Figure 2. Photographic examples of CSG evaporation dam after dewatering (A) and close up of CSG sediment (B) in the Bowen Basin, 2013.

Moreover, given transpoevaporation rates in Queensland heavily favor water rather than evaporation, particularly in the summer months from December through March, the result for most CSG sites is a net accumulation of settled solids, as shown in Figures 1B and 2 after dewatering. With about 500 million tonnes of solids generated in Queensland during 2012 and a further projected 2.5 billion tonnes accumulating by 2020, the question of how to sustainably manage CSG sediments is a growing concern to regulators, industry and local farming communities.

As a consequence, operators are required to develop environmental plans which manage the high volumes of produced water and waste sediments that accumulate as a result of CSG production. There are, however, no formal compliance standards for contaminated CSG liquid or solid wastes in Queensland, with each operator negotiating a "sustainable" management plan on a site-by-site basis coupled with self-reporting of results and compliance [11].

Despite the fact that only a few years ago construction of new evaporation dams was being phased out and decommissioning the encouraged option [12], today ever larger dams are being constructed to handle the exponential increase in water and sediment volumes. Current best practice means that when a dam becomes no longer viable, the most preferred practice is to remove residual wastewater, cover the sediment with clean fill, contour the dam into a stable landform, revegetate with salt-tolerant grass species, and leave the untreated sediment in-situ.

Attempts at deep-well injection and offshore submarine disposal of CSG sediments have been considered, but these methods are in their infancy and have not gained widespread public acceptance [6].

Moreover, beneficial reuse of CSG sediments as "clean fill" for levy, dam wall and road construction, and other applications in agriculture (such as forestry using salt-tolerant species like western wattle [Acacia saligna] and black oak [Casaurina cristata pauper] or biofuel production using salt-tolerant safflowers [Carthamus tinctorius] and sunflowers [Helianthus annuus] as sources of polyunsaturated fatty acids) have been contemplated, but most potential reuse solutions have been found wanting either due to the highly saline properties of sediments or low tolerance levels for innovation from local farming communities and the wider society due to fears of downstream environmental contamination [8].

Therefore, in order to investigate whether treated CSG dam sediments are amendable to beneficial reuse, this study asked the following research questions: Experiment \#1-can two different types of CSG dam sediments from Queensland be remediated to Australian standards of "clean, usable soil" using two rates of direct addition of chemicals and natural fertilizers; and Experiment \#2-are remediated dam sediments responsive to revegetation using non-salt-tolerant grass species?

\section{Method}

\subsection{Experiment \#1}

A site with 70+ operating CSG wells and four evaporation dams in the Bowen Basin was chosen for the field trial, which was conducted during December 2013. At this site, $7.0 \mathrm{~m}^{3}$ samples of sediment were excavated from two evaporation dams. Based on previous records, the sediments from these two dams would represent the low and high ends of the salinity range. Sediment A was excavated using a backhoe from a decommissioned, but untreated, dam in which $1,900 \mathrm{~m}^{3}$ sediments had been atmospherically dried and stockpiled over a three-month period; this dam was located at the centre of the site. As shown in Figure 3A, Sediment A was a fine-grained, silty grey clay of medium density, with obvious white patches of salt on its surface; the sediment contained a significant portion of organic matter and $2-10 \mathrm{~mm}$ mixed gravels, but did not emanate any odour.

Sediment B was excavated from under the water column of a second evaporation dam $15 \mathrm{~km}$ to the south of the first; the second dam contained an estimated $6,300 \mathrm{~m}^{3}$ of sediment and was still in production at the time of the field trial (the dam is shown in Figure 1A). Sediment B was atmospherically dewatered for three days prior to the trial at an average daytime temperature of $25^{\circ} \mathrm{C}$. As shown in Figure 6A, 
Sediment B was a fine-grained, silty grey-brown clay of medium density; the sediment contained little organic matter and did not emanate any odour. The two CSG dam sediment samples were transported to a central $70 \mathrm{~m} \times 70 \mathrm{~m}$ designated treatment area (DTA) in the centre of the site where the field trial was conducted.

As shown in Tables 1 and 2, untreated Sediment A had a lower moisture content than Sediment B $(27.4 \%$ versus $49.3 \%$ ), consistent with the sources of sediment on this site, a higher electrical conductivity (EC, $9.39 \mathrm{mS} / \mathrm{cm}$ versus $2.06 \mathrm{mS} / \mathrm{cm})$ due to higher total concentrations of $\mathrm{Na}$ $(16,100 \mathrm{mg} / \mathrm{kg}$ versus $4,090 \mathrm{mg} / \mathrm{kg})$ and $\mathrm{Cl}(19,900 \mathrm{mg} / \mathrm{kg}$ versus $5,400 \mathrm{mg} / \mathrm{kg})$, and a higher total alkalinity $(6,290 \mathrm{mg} / \mathrm{kg}$ versus $1,320 \mathrm{mg} / \mathrm{kg}$ ). CEC and SAR are particularly relevant in this study because both relate to soil fertility. Cation-exchange capacity (CEC) measures the total number of cations available for exchange with water as a result of negatively charged particles in the sediment holding positively charged cations by electrical attraction.

The four most important cations in this study are calcium $\left(\mathrm{Ca}^{+}\right)$, magnesium $\left(\mathrm{Mg}^{+}\right)$, potassium $\left(\mathrm{K}^{+}\right)$, and sodium $\left(\mathrm{Na}^{+}\right)$; these four cations are held to the sediment by negatively charged particles present within the sediment matrix. A CEC of $24 \mathrm{meq} / 100 \mathrm{~g}$ for Sediment A and $25 \mathrm{meq} / 100 \mathrm{~g}$ for Sediment $\mathrm{B}$ is normal for clay-like material with a $\mathrm{pH} \pm 10.0$. Similarly, SAR measures sodicity in sediments which can be extracted by water and is therefore also an important factor in determining soil structure and fertility (SAR equals the total concentration of $\mathrm{Na}$ in the sediment divided by the square root of $\mathrm{Ca}$ added to $\mathrm{Mg}$ divided by two). As soils with a $\mathrm{SAR}>6.0 \mathrm{meq} / 100 \mathrm{~g}$ are classified as "sodic" in Australia [13], both Sediment A at $931 \mathrm{meq} / 100 \mathrm{~g}$ and Sediment B at $189 \mathrm{meq} / 100 \mathrm{~g}$ would be classified as extremely sodic.

From the data presented in Tables 1 and 2, it is therefore reasonable to conclude that Sediments A and B are both sodic (due to the presence of high concentrations of $\mathrm{Na}^{+}$) and saline (due to the presence of high concentrations of $\mathrm{Na}^{+}$and $\mathrm{Cl}^{-}$). Of note also is the presence of heavy metals in the sediments (particularly arsenic, chromium, copper, lead, nickel and zinc), although metals were universally non-leachable and non-bioavailable; the presence of heavy metals in sediments were therefore predicted to have no adverse impact on revegetation.

Leachability of metals was ascertained by the Toxic Characteristic Leaching Procedure (TCLP) analyzed by inductively coupled plasma atomic emission spectrometry (ICP-AES). As no evidence was found for the presence of phenols, benzene, toluene, ethylbenzene, xylene, polycyclic aromatic hydrocarbons, alkanic hydrocarbons or organochlorine pesticides in either Sediments A or B, these data have not been included in Tables 1 and 2 .

Each sample was divided into two equal parts, with each 3.5 $\mathrm{m}^{3}$ labelled: Sediment A1; Sediment A2; Sediment B1; and Sediment B2. The weight of each biopile of excavated sediment was estimated to be $5.25 \mathrm{t}$ (bulk density $=1.5$ ), and measured approximately $2.0 \mathrm{~m} \mathrm{~L} \mathrm{x} 2.0 \mathrm{~m} \mathrm{~W} \times 1.0 \mathrm{~m} \mathrm{H}$ when placed as piles in the DTA. For the purposes of consistency, all additive measurements in this study are given on a dry wt/wt basis.

Treatment of Sediment A1 using a backhoe followed this procedure:

Add $150 \mathrm{~kg}$ of modified alumina refinery residue (MARR) ( $3 \% \mathrm{wt} / \mathrm{wt}$ ) to stabilize $\mathrm{pH}$, add micronutrients such as sulfate $\left(\mathrm{SO}_{4}\right)$, and consolidate physical properties of sediment through the addition of silica $(\mathrm{Si})$ and iron $(\mathrm{Fe})$;

Mix thoroughly until visually homogenous;

Add approximately 100L of water as required to aid mixing; Add $15 \mathrm{~kg}$ of ferrous sulfate heptahydrate $\left(\mathrm{FeSO}_{4}\right)(0.3 \%$ $\mathrm{wt} / \mathrm{wt}$ ) to reduce $\mathrm{pH}$;

Add $25 \mathrm{~kg}$ of nitrogen-phosphorus-potassium fertilizer $(0.5 \% \mathrm{wt} / \mathrm{wt})$ to provide macronutrients;

Mix thoroughly until visually homogenous;

Add approximately $100 \mathrm{~L}$ water as required to aid mixing;

Add $80 \mathrm{~kg}$ of locally produced oaten farm hay as a carbon source and mix thoroughly;

Collect four x 500g samples from the front left, front right, back left, and back right of pile and commingle to form one $\mathrm{x}$ $2.0 \mathrm{~kg}$ sample; and

Send $500 \mathrm{~g}$ commingled sample to an independent laboratory in Brisbane, and analyze sample for analytes listed in Table 1.

Treatment of Sediment A2 followed the same procedure, except:

Add $1,000 \mathrm{~kg}$ of MARR $(20 \% \mathrm{wt} / \mathrm{wt})$;

Add $300 \mathrm{~kg}$ of $\mathrm{FeSO}_{4}(6 \% \mathrm{wt} / \mathrm{wt})$; and

Add $100 \mathrm{~kg}$ of NPK fertilizer ( $2 \% \mathrm{wt} / \mathrm{wt})$.

Treatments of Sediment B1 followed the same procedure as Sediment A1, and Sediment B2 followed the same procedure as Sediment A2.

Alumina refinery residue, sometimes referred to as bauxite residue or Bayer Process residue, has been used in the mining industry to neutralize acid and sequester heavy metals in tailings [14, 15]; its modification for reuse in environmental remediation and industrial waste treatment projects as MARR has been outlined elsewhere [16, 17].

In this study, MARR had a $\mathrm{pH}$ of 9.5 (i.e., roughly the same as the untreated sediments in the field trial), and was high in carbonate, hydroxide and hydroxycarbonate minerals. MARR also contained a cocktail of metals and minerals, including hematite $\left(\mathrm{Fe}_{2} \mathrm{O}_{3}\right)$, beohmite $(\mathrm{AlOOH})$, gibbsite $\left(\mathrm{Al}[\mathrm{OH}]_{3}\right)$ and sodalite $\left(\mathrm{Na}_{4} \mathrm{Al}_{3} \mathrm{Si}_{3} \mathrm{O}_{12} \mathrm{Cl}\right)$, anatase $\left(\mathrm{TiO}_{2}\right)$, aragonite $\left(\mathrm{CaCO}_{3}\right)$, brucite $\left(\mathrm{Mg}[\mathrm{OH}]_{2}\right)$, diaspore $\left(\mathrm{Al}_{2} \mathrm{O}_{3} \cdot \mathrm{H}_{2} \mathrm{O}\right)$, ferrihydrite $\left(\mathrm{Fe}_{5} \mathrm{O}_{7}[\mathrm{OH}] \cdot 4 \mathrm{H}_{2} \mathrm{O}\right)$, gypsum $\left(\mathrm{CaSO}_{4} \cdot 2 \mathrm{H}_{2} \mathrm{O}\right)$, hydrocalumite $\left(\mathrm{Ca}_{2} \mathrm{Al}[\mathrm{OH}]_{7} \cdot 3 \mathrm{H}_{2} \mathrm{O}\right)$, hydrotalcite $\left(\mathrm{Mg}_{6} \mathrm{Al}_{2} \mathrm{CO}_{3}[\mathrm{OH}]_{16} \cdot 4 \mathrm{H}_{2} \mathrm{O}\right)$, and p-aluminohydrocalcite $\left(\mathrm{CaAl}_{2}\left[\mathrm{CO}_{3}\right]_{2}[\mathrm{OH}]_{4} \cdot 3 \mathrm{H}_{2} \mathrm{O}\right)$. Of significance in these formulae was the presence of oxyhydroxide compounds as well as negatively charged iron-, aluminium-, magnesium- and titanium-based molecules, which not only adsorb positively charged cations but also lead to precipitation and isomorphic substitution reactions; these reactions are responsible for long-term sequestration phenomena of positively charged cationic and negatively charged anionic species. These and other relevant phenomena identified with MARR at metaliferous mine sites around the 
world have been discussed elsewhere [18], and applications utilizing these and related reagents in the treatment of coal waste and in industrial site remediation have been examined $[19,20,21]$. To this author's knowledge, MARR has never been applied to CSG produced water or sediments.
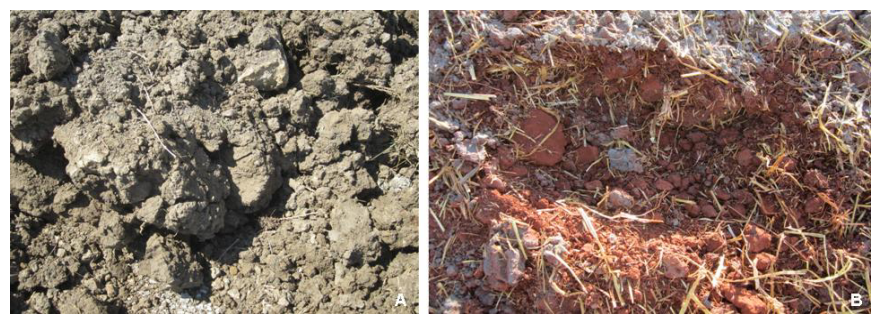

Figure 3. Sediment $A(A)$ and Sediment $A 1(B)$.

The $\mathrm{FeSO}_{4}$ applied in step D was a commercial-grade, $>98 \%$ pure, grey-white, soluble solid with a $\mathrm{pH}$ of 3.5 ; the NPK fertilizer applied in step E was a commercially available, light brown, soluble fertilizer containing $\mathrm{N}=23.8 \%, \mathrm{P}=3.7 \%, \mathrm{~K}=13 \%$, and sulfur $(\mathrm{S})=$ $4.1 \%$ with a $\mathrm{pH}$ of 4.0 ; and the oaten hay (a combination of Avena byzantine [red oats] and Avena sativa [white oats]) applied in step $\mathrm{H}$ was sourced locally from an adjoining farm and had a $\mathrm{pH}$ of \pm 5.0 .

\subsection{Experiment \#2}

At the completion of Experiment \#1,300g samples of Sediment A, Sediment A1, Sediment A2, Sediment B, Sediment B1, and Sediment B2 were collected; all six samples were placed in separate plastic trays measuring $200 \mathrm{~mm} x$ $200 \mathrm{~mm}$; large pieces of oaten hay, clods of clay and gravel were removed to allow for improved sample consolidation. Each tray had approximately $15 \times 4.0 \mathrm{~mm}$ holes drilled through the base of the tray prior to sediment addition to allow for efficient drainage. This resulted in approximately $50 \mathrm{~mm}$ of sediment in each tray, photographs of which are shown in Figures 4 and 5 .

A standard, non-salt-tolerant grass species (i.e., Munns over-sow lawn seed) was sprinkled onto the surface of all six samples, with approximately 150 seeds added per tray. The seeds were then covered with $0.5 \mathrm{~cm}$ of clean soil (to replicate what would occur as part of the site's sustainable rehabilitation program) to aid in germination. Trays were lightly watered each day for ten days and left in the open sunlight; temperatures during the bench-scale test averaged $25-30^{\circ} \mathrm{C}$ throughout the experimental period. Photographs of each tray were taken on day one (see Figures 3 and 4) and after seeds had germinated on day ten in order to document establishment height and density rates.

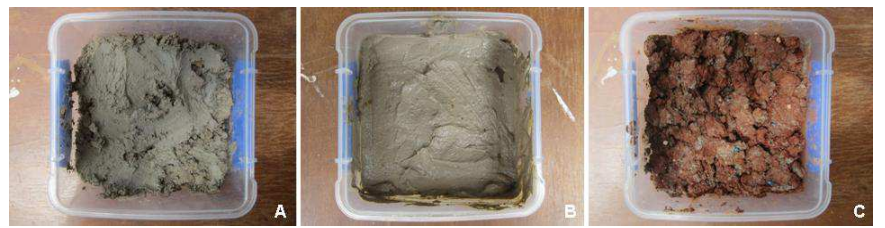

Figure 4. Sediment B (A); Sediment B1 (B); and Sediment B2 (C) on day one before seeding and topsoil.

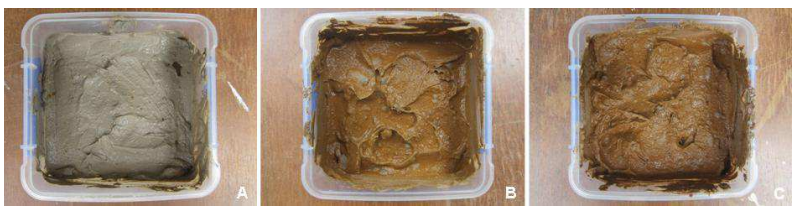

Figure 5. Sediment B (A); Sediment B1 (B); and Sediment B2 (C) on day one before seeding and topsoil.

\section{Results}

\subsection{Experiment \#1}

There are no guidelines for what constitutes "clean soil" in Queensland. Therefore, two other Australian standards were used in this study to determine the analytical baseline from which an empirical measure of "clean, usable soil" could be applied. First, the Victorian Government's Environment Protection Authority soil hazard categorization for "clean fill" [22]; this standard is used throughout Australia as a criterion for determining soil which is not contaminated.

Second, the National Environment Protection assessment of site contamination, the so-called NEPM guidelines; this study applied health investigation Level ' $F$ ' of the guidelines, which relates to determining "clean industrial soil" [23]. While there is no limit for total phosphorus (TP) under NEPM Level ' $F$ ', there is a $2,000 \mathrm{mg} / \mathrm{kg}$ TP limit under its Ecological Investigation Level for urban environments, which has therefore been applied in this study. Sediments A1, A2, B1 and B2 were compared to these two standards to determine whether they met the criterion of "clean, usable soil".

Table 1. Physical and chemical properties of untreated Sediment A, treated Sediments A1 and A2, compared to Victorian EPA soil criteria for "clean fill" and NEPM criteria for "clean industrial soil".

\begin{tabular}{|c|c|c|c|c|c|c|}
\hline Parameter & $\begin{array}{l}\text { Untreated Sediment } \\
\text { A }\end{array}$ & $\begin{array}{l}\text { Treated Sediment } \\
\text { A1 }\end{array}$ & $\begin{array}{l}\text { Treated Sediment } \\
\text { A2 }\end{array}$ & $\begin{array}{l}\text { Victorian EPA Clean } \\
\text { Fill }\end{array}$ & $\begin{array}{l}\text { NEPM } \\
\text { Soil }\end{array}$ & Clean \\
\hline Moisture content (\%) & 28 & 14 & 30 & NL & NL & \\
\hline$p H$ & 10.0 & 8.5 & 7.4 & NL & NL & \\
\hline$E C(\mathrm{mS} / \mathrm{cm})$ & 9.3 & 5.9 & 8.2 & NL & NL & \\
\hline Calcium (mg/kg) & 10 & 200 & 1,740 & NL & NL & \\
\hline Magnesium (mg/kg) & $<10^{\dagger}$ & 90 & 530 & NL & NL & \\
\hline Potassium (mg/kg) & 340 & 380 & 1,710 & NL & NL & \\
\hline Sodium $(\mathrm{mg} / \mathrm{kg})$ & 16,100 & 7,380 & 9,970 & NL & NL & \\
\hline
\end{tabular}




\begin{tabular}{|c|c|c|c|c|c|c|c|c|}
\hline Parameter & $\begin{array}{l}\text { Untreated Sediment } \\
\text { A }\end{array}$ & $\begin{array}{l}\text { Treated } \\
\text { A1 }\end{array}$ & Sediment & $\begin{array}{l}\text { Treated } \\
\text { A2 }\end{array}$ & Sediment & $\begin{array}{l}\text { Victorian EPA Clean } \\
\text { Fill }\end{array}$ & $\begin{array}{l}\text { NEPM } \\
\text { Soil } \\
\end{array}$ & Clean \\
\hline Chloride (mg/kg) & 19,900 & 9,450 & & 1,770 & & NL & NL & \\
\hline Phosphorus (mg/kg) & 27 & 554 & & 855 & & 2,000 & 2,000 & \\
\hline Nitrogen $(m g / k g)$ & 656 & 1,440 & & 2,550 & & NL & NL & \\
\hline $\begin{array}{l}\text { Cation-exchange capacity } \\
\text { (meq/100g) }\end{array}$ & 24 & 11 & & 4.0 & & NL & NL & \\
\hline $\begin{array}{l}\text { Sodium adsorption ratio } \\
\text { (meq/100g) }\end{array}$ & 931 & 68 & & 44 & & NL & NL & \\
\hline Total alkalinity $(\mathrm{mg} / \mathrm{kg})$ & 6,290 & 1,800 & & 391 & & NL & NL & \\
\hline Arsenic (mg/kg) & $<5.0^{\dagger}$ & 5.0 & & 9.0 & & 20 & 500 & \\
\hline Cadmium (mg/kg) & $<1.0^{\dagger}$ & $<1.0^{\dagger}$ & & $<1.0^{\dagger}$ & & 3.0 & 100 & \\
\hline Chromium (mg/kg) & 11 & 32 & & 110 & & NL & NL & \\
\hline Copper $(\mathrm{mg} / \mathrm{kg})$ & 10 & 10 & & 10 & & 100 & 5,000 & \\
\hline Lead $(\mathrm{mg} / \mathrm{kg})$ & 10 & 14 & & 20 & & 300 & 1,500 & \\
\hline Mercury (mg/kg) & $<1.0^{\dagger}$ & $<1.0^{\dagger}$ & & $<1.0^{\dagger}$ & & 1.0 & 75 & \\
\hline Nickel (mg/kg) & 6.0 & 10 & & 14 & & 60 & 3,000 & \\
\hline Zinc (mg/kg) & 21.0 & 19.0 & & 20 & & 200 & 35,000 & \\
\hline Leachable Arsenic (mg/L) & $<0.1^{\dagger}$ & $<0.1^{\dagger}$ & & $<0.1^{\dagger}$ & & $<0.7$ & NL & \\
\hline Leachable Cadmium $(\mathrm{mg} / \mathrm{L})$ & $<0.05^{\dagger}$ & $<0.05^{\dagger}$ & & $<0.05^{\dagger}$ & & $<0.2$ & NL & \\
\hline Leachable Chromium $(\mathrm{mg} / \mathrm{L})$ & $<0.1^{\dagger}$ & $<0.1^{\dagger}$ & & $<0.1^{\dagger}$ & & $<5.0$ & NL & \\
\hline Leachable Copper $(m g / L)$ & $<0.1^{\dagger}$ & $<0.1^{\dagger}$ & & $<0.1^{\dagger}$ & & $<200$ & NL & \\
\hline Leachable Lead $(\mathrm{mg} / \mathrm{L})$ & $<0.1^{\dagger}$ & $<0.1^{\dagger}$ & & $<0.1^{\dagger}$ & & $<1.0$ & NL & \\
\hline Leachable Mercury $(\mathrm{mg} / \mathrm{L})$ & $<0.001^{\dagger}$ & $<0.001^{\dagger}$ & & $<0.001^{\dagger}$ & & $<0.1$ & NL & \\
\hline Leachable Nickel (mg/L) & $<0.1^{\dagger}$ & $<0.1^{\dagger}$ & & $<0.1^{\dagger}$ & & $<2.0$ & NL & \\
\hline Leachable Zinc $(m g / L)$ & $<0.1^{\dagger}$ & $<0.1^{\dagger}$ & & $<0.1^{\dagger}$ & & $<300$ & NL & \\
\hline
\end{tabular}

${ }^{\dagger}$ Below level of detection; $\mathrm{NL}=$ no limit.

Figure 3B shows a close-up photograph of Sediment A1, which was visually identical to Sediment A2. Clearly evident in this image is the red-coloured MARR (30-40\% of which is composed of $\mathrm{Fe}_{2} \mathrm{O}_{3}$ ) and oaten hay; some evidence for a mottled salty precipitate is also visible in this photograph. Table 1 presents the analytical data for Sediments A, A1 and $\mathrm{A} 2$, and compares these data to the Victorian EPA guidelines for "clean fill" and the NEPM guidelines for "clean industrial soil". From these data it can be seen that the $\mathrm{pH}$ of Sediment A was reduced from 10.0 to 8.5 in Sediment A1 and to a near-neutral 7.4 in Sediment A2; EC was reduced from $9.3 \mathrm{mS} / \mathrm{cm}$ to $5.9 \mathrm{mS} / \mathrm{cm}$ in Sediment A1 but remained largely unchanged in Sediment A2.

CEC was reduced from $24 \mathrm{meq} / 100 \mathrm{~g}$ to $11 \mathrm{meq} / 100 \mathrm{~g}$ (a $50 \%$ reduction) in Sediment Al and to $4.0 \mathrm{meq} / 100 \mathrm{~g}$ (an $84 \%$ reduction) in Sediment A2, and SAR was reduced from $931 \mathrm{meq} / 100 \mathrm{~g}$ to $68 \mathrm{meq} / 100 \mathrm{~g}$ (a $93 \%$ reduction) in Sediment A1 and to $44 \mathrm{meq} / 100 \mathrm{~g}$ (a $95 \%$ reduction) in Sediment A2. Total heavy metal concentrations remained largely unchanged in both treated sediments as would be expected (although $\mathrm{Cr}$ increased for reasons which are not obvious, although cross-contamination from MARR and NPK are possible), and leachable metals were below detection limits both before and after treatment.

Total alkalinity decreased from $6,290 \mathrm{mg} / \mathrm{kg}$ to $1,800 \mathrm{mg} / \mathrm{kg}$ (an $84 \%$ reduction) in Sediment A1 and $391 \mathrm{mg} / \mathrm{kg}$ (a $94 \%$ reduction) in Sediment $\mathrm{A} 2, \mathrm{Ca}, \mathrm{Mg}$ and $\mathrm{K}$ increased in both treated sediments, which would be expected given MARR contains significant amounts of both $\mathrm{Ca}$ and $\mathrm{Mg}$ and NPK contains $13 \% \mathrm{~K}$, but $\mathrm{Na}$ decreased from $16,100 \mathrm{mg} / \mathrm{kg}$ to $7,380 \mathrm{mg} / \mathrm{kg}$ (a $55 \%$ reduction) in Sediment $\mathrm{A} 1$ and $9,970 \mathrm{mg} / \mathrm{kg}$ (a $39 \%$ reduction) in Sediment $\mathrm{A} 2$, and $\mathrm{Cl}$ decreased from $19,900 \mathrm{mg} / \mathrm{kg}$ to $9,450 \mathrm{mg} / \mathrm{kg}$ (a $53 \%$ reduction) in Sediment A1 and $1,770 \mathrm{mg} / \mathrm{kg}$ (a $91 \%$ reduction) in Sediment A2. Total phosphorus (TP) and total nitrogen (TN) both increased significantly due to the addition of NPK.

Figure 6B shows a close-up photograph of Sediment B1, which was visually identical to Sediment B2. Clearly evident in this image is the red-coloured MARR and oaten hay; some evidence of a mottled salty precipitate is also visible in this photograph. Table 2 presents the analytical data for Sediments B, B1 and B2, and compares these data to the Victorian EPA guidelines for "clean fill" and the NEPM guidelines for "clean industrial soil".

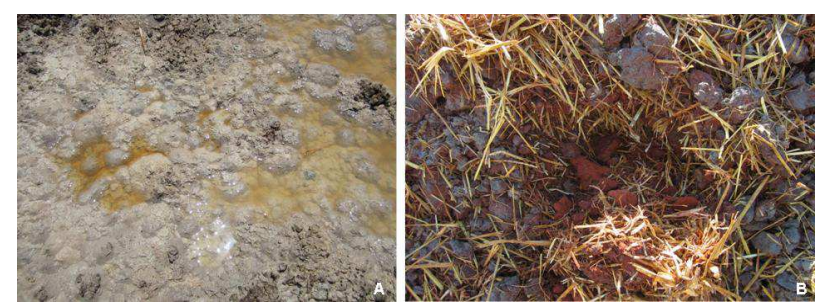

Figure 6. Sediment $B(A)$ and Sediment $B 1(B)$. 
Table 2. Physical and chemical properties of untreated Sediment B, treated Sediments B1 and B2, compared to Victorian EPA soil criteria for "clean fill" and NEPM criteria for "clean industrial soil".

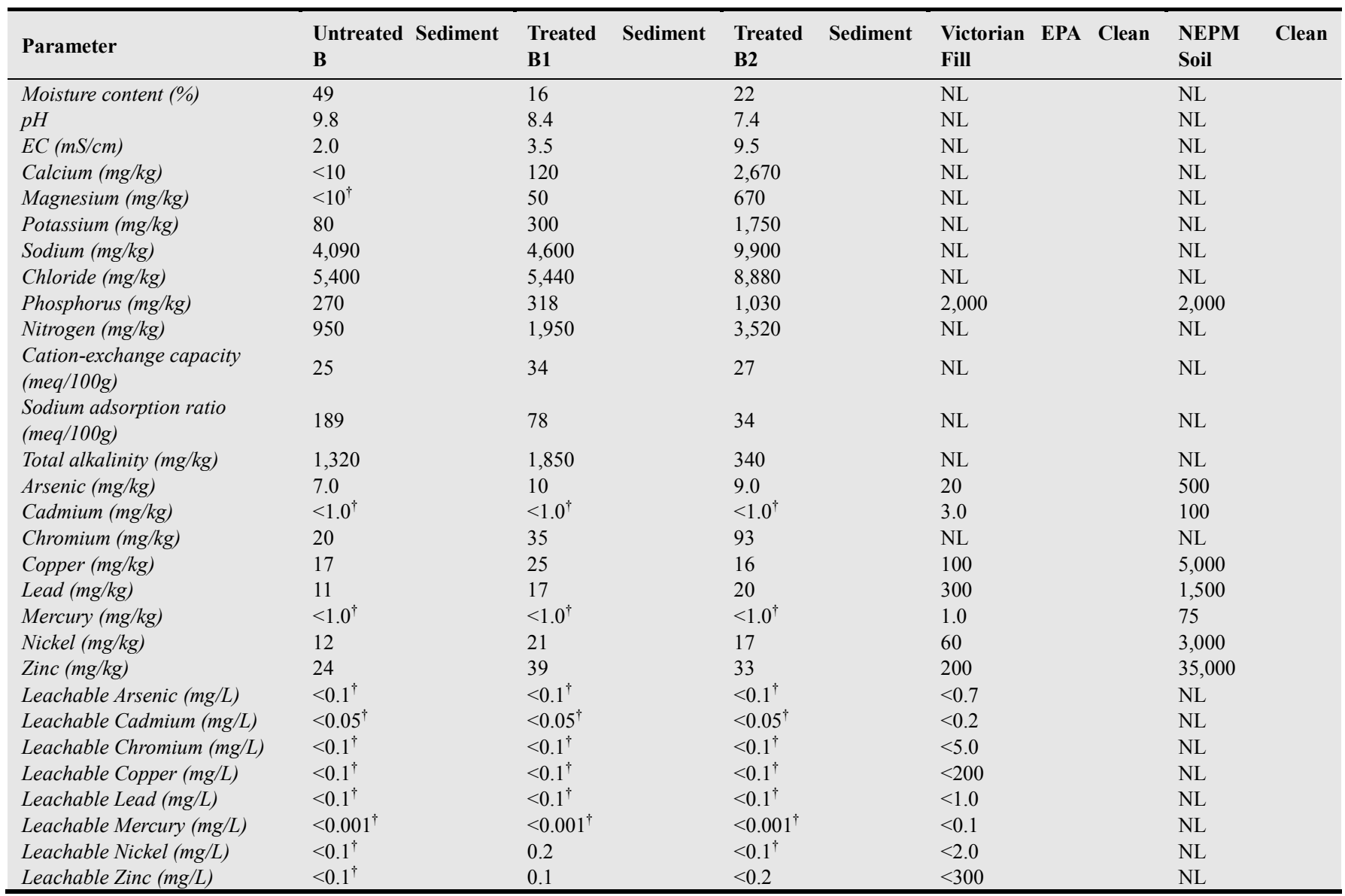

${ }^{\dagger}$ Below level of detection; $\mathrm{NL}=$ no limit.

From these data it can be seen the $\mathrm{pH}$ of Sediment B was reduced from 9.8 to 8.4 in Sediment B1 and to a near-neutral 7.4 in Sediment B2; however, EC increased from $2.0 \mathrm{mS} / \mathrm{cm}$ to $3.5 \mathrm{mS} / \mathrm{cm}$ in Sediment B1 and $9.5 \mathrm{mS} / \mathrm{cm}$ in Sediment B2, presumably as a result of MARR addition, although it is not clear why this would occur in one sediment and not the other.

CEC remained largely unchanged in both sediments, but SAR was reduced from $189 \mathrm{meq} / 100 \mathrm{~g}$ to $78 \mathrm{meq} / 100 \mathrm{~g}$ (a $59 \%$ reduction) in Sediment B1 and to $34 \mathrm{meq} / 100 \mathrm{~g}$ (an $83 \%$ reduction) in Sediment B2. As observed in Sediments A1 and A2, total heavy metals remained largely unchanged in both treated sediments as would be expected (although $\mathrm{Cr}$ and $\mathrm{Pb}$ increased for reasons which are not immediately obvious, although cross-contamination from MARR and NPK are possible), and leachable metals were below detection limits both before and after treatment for most metals.

Total alkalinity increased by $40 \%$ from $1,320 \mathrm{mg} / \mathrm{kg}$ to $1,850 \mathrm{mg} / \mathrm{kg}$ in Sediment B1, but decreased to $340 \mathrm{mg} / \mathrm{kg}$ (a $75 \%$ reduction) in Sediment $\mathrm{B} 2, \mathrm{Ca}, \mathrm{Mg}$ and $\mathrm{K}$ increased in both treated sediments, which would be expected given MARR contains significant amounts of both $\mathrm{Ca}$ and $\mathrm{Mg}$ and NPK contains $13 \% \mathrm{~K}$, but $\mathrm{Na}$ remained unchanged in Sediment B1 but increased by $60 \%$ from $4,090 \mathrm{mg} / \mathrm{kg}$ to $9,900 \mathrm{mg} / \mathrm{kg}$ in Sediment B2, and $\mathrm{Cl}$ similarly remained unchanged in Sediment B1 and increased by $40 \%$ from
$5,400 \mathrm{mg} / \mathrm{kg}$ to $8,880 \mathrm{mg} / \mathrm{kg}$ in Sediment B2. TP and TN both increased due to the addition of NPK.

\subsection{Experiment \#2}

Most or all 150 lawn seeds appear to have germinated in Sediments A1, A2, B1 and B2, but not in untreated Sediments A and B, with the average height of seedlings at $30 \mathrm{~mm}$ in Sediments A and B, 60mm in Sediments A1 and $\mathrm{B} 1$, and $90 \mathrm{~mm}$ in Sediments A2 and B2.
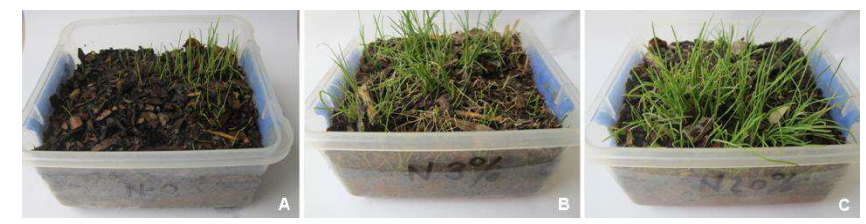

Figure 7. Sediment A (A); Sediment A1 (B); and Sediment $A 2(C)$ on day ten.
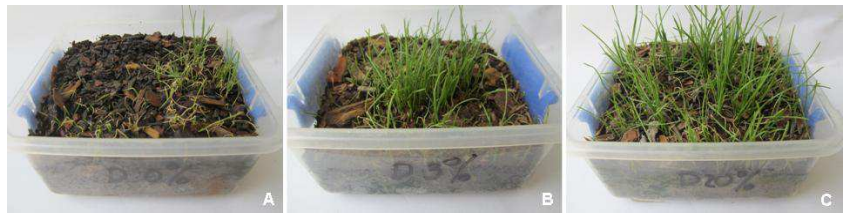

Figure 8. Sediment B (A); Sediment B1 (B); and Sediment B2 (C) on day ten. 
Figures 7 and 8 show the results of the bench-scale test to revegetate Sediments A, A1, A2, B, B1 and B2, in which it is clear that seeds had germinated and established in all six sediment trays by day ten. In order of greatest height and density of seedlings, these can visually be rated for Sediment A: 1) untreated Sediment A; 2) treated Sediment A1; and 3) treated Sediment A2, with the same observation for Sediment B. It is of interest to note that seedlings in both untreated sediments in Figures 7A and 8A only established in about 25\% of the tray, despite being spread evenly over the surface of the sediment, whereas seedlings in $7 \mathrm{~B}, 7 \mathrm{C}, 8 \mathrm{~B}$ and $8 \mathrm{C}$ have established across the entire surface of the tray.

\section{Conclusions}

The CSG dam sediments used in this study were both saline and sodic, rendering them unsuitable for beneficial reuse, particularly in revegetation projects and agriculture. However, it is reasonable to conclude that the remediation of CSG dam sediments from Queensland described in this field trial using the direct addition of MARR, $\mathrm{FeSO}_{4}$, NPK fertilizer, and oaten hay was effective in converting contaminated CSG sediments into potentially reusable soil media when comparing the results to Victorian EPA guidelines for clean fill and NEPM guidelines for clean industrial soil. In fact, concentrations of contaminants in Sediments A1, A2, B1 and B2 were lower than the recommended limits for all parameters, thereby meeting the "clean, usable soil" criterion set forth in this study.

However, it should be stated that both sets of guidelines do not include a comprehensive list of all relevant soil fertility and structure factors, particularly EC, CEC, SAR, and total sodium and chloride. For example, electrical conductivity is a key measure of soil salinity not included in either the Victorian EPA or NEPM guidelines. The recommended limit of EC for "salt-sensitive" and "moderately salt-sensitive" crops and pasture species (such as potatoes and clover) is $0-2.0 \mathrm{mS} / \mathrm{cm}$ and for "moderately salt-tolerant species" (such as sorghum and lucerne) is $2.0-4.0 \mathrm{mS} / \mathrm{cm}$ [24]. Only Sediment B1 would be suitable for beneficial reuse with moderately tolerant species but not for salt-sensitive species. Similarly, Sediment A1 would be suitable for "salt-tolerant species" (such as sunflower and ryegrass), which can survive in soil with an EC in the $4.0-8.0 \mathrm{mS} / \mathrm{cm}$ range, but Sediments $\mathrm{A} 2$ and $\mathrm{B} 2$ would only be suitable for reuse with "very salt-tolerant" species (such as barley and wheat grass) in the EC $8.0-16 \mathrm{mS} / \mathrm{cm}$ range. Any soil with an EC $>16 \mathrm{mS} / \mathrm{cm}$ is too saline for crops to be productive, but some pasture species, including salt bush and inland salt-grass, can survive [24, 25].

Similarly, further investigation is needed to shed light on the function of CEC and its relation to revegetation in CSG dam sediments. As noted above, the CEC for both Sediments $\mathrm{A}$ and $\mathrm{B}$ was normal at $24-25 \mathrm{meq} / 100 \mathrm{~g}$ before treatment and would be suitable when considering the beneficial reuse of sediments in revegetation. However, while treatments B1 and $\mathrm{B} 2$ had no significant effect on $\mathrm{CEC}$, as a result of remediation, the CEC was significantly reduced by $55 \%$ from $24 \mathrm{meq} / 100 \mathrm{~g}$ to $11 \mathrm{meq} / 100 \mathrm{~g}$ in Sediment $\mathrm{A} 1$ and by $84 \%$ to $4.0 \mathrm{meq} / 100 \mathrm{~g}$ in
Sediment A2. These levels of CEC may not be advantageous for revegetation over the long term.

A reduction to $\mathrm{pH}$ can also reduce the $\mathrm{CEC}$ of soils and sediments, however the reductions in $\mathrm{pH}$ observed in this study cannot explain the reduction to CEC in Sediment A because the $\mathrm{pH}$ of Sediments B1 and B2 were reduced by the same orders of magnitude as Sediments A1 and A2 without the same commensurate changes to CEC. Increases in organic matter, which occurred in all four treatments as a result of hay addition, should have also increased CEC due to increases in $\mathrm{pH}$ [13], but the phenomenon was not observed in this study for Sediments A1 and A2. If the oaten hay used in this field trial had been reduced in size by shredding prior addition it may have liberated carbon and affected $\mathrm{pH}$ (and hence CEC) of remediated sediments.

Moreover, while the reductions to CEC in Sediments A1 and A2 apparently did not hinder revegetation as shown in Experiment \#2, the interactions between exchangeable $\mathrm{Ca}$ (which was $15 \mathrm{meq} / 100 \mathrm{~g}$ in Sediment A but $5.0 \mathrm{meq} / 100 \mathrm{~g}$ in Sediment A1 and $1.5 \mathrm{meq} / 100 \mathrm{~g}$ in Sediment A2) and exchangeable $\mathrm{Na}$ (which was $7.0 \mathrm{meq} / 100 \mathrm{~g}$ in Sediment A but $3.4 \mathrm{meq} / 100 \mathrm{~g}$ in Sediment A1 and $1.2 \mathrm{meq} / 100 \mathrm{~g}$ in Sediment A2) should be the subject of further inquiry, because soil fertility (specifically, spontaneous and mechanical soil dispersion) is related to an increase in exchangeable $\mathrm{Mg}$ and $\mathrm{K}$ at the expense of $\mathrm{Ca}$ in the presence of $\mathrm{Na}$ in clay-like soil media [13].

Likewise, while the elevated levels of SAR apparently did not hinder revegetation of remediated sediments in this study as shown in Experiment \#2, long-term growth rates and crop yields have not been investigated, and it is possible these would be compromised by the presence of high concentrations of $\mathrm{Na}$ in the remediated sediments.

From this data is can be concluded that a 3-4\% wt/wt addition rate of chemical reagents and additives used in this field trial resulted in more viable revegetation when measuring density and height of plant growth compared to untreated sediment. It can also be concluded that a $28 \% \mathrm{wt} / \mathrm{wt}$ addition rate resulted in the establishment of even more viable revegetation compared to the $3-4 \%$ addition rate, suggesting that with higher addition rates, and hence availability of more macro- and micro-nutrients, CSG dam sediments become more amendable to revegetation. To verify this statement, larger scale and longer term studies should be conducted, and the use of more salt-tolerant grass species, such as katambora rhodes (Chloris gayana), gayndah buffel (Cenchrus ciliaris), bisset creeping blue (Bothriochloa insculpta), and bambatsi panic (Panicum coloratum), which thrive in pastures around the evaporation dams at the field trial site, should be tested in future.

However, it is reasonable to conclude that the remediation of two different types of CSG dam sediments from Queensland using the direct addition and mixing of a combination of MARR, $\mathrm{FeSO}_{4}$, NPK fertilizer, and oaten hay was effective in converting salt-contaminated sediments into a potentially beneficial reusable soil medium, but further investigation into the suitability of treated CSG sediments as "clean, usable soil" is required before sound, scientific conclusions can be drawn. 


\section{References}

[1] Day, R.W. (2009). Coal seam gas booms in eastern Australia. Feature Paper, Preview, June 2009.

[2] Baker, G. and Slater, S. (2008). Coal seam gas: An increasingly significant source of natural gas in eastern Australia, PESA EABS III Symposium, Sydney, September 14-17, 2008, 378-391.

[3] Department of Natural Resources and Mines (2014). Queensland's coal seam gas overview. Department of Natural Resources and Mines, Report No. B/Brochures/CSG/CC13PET001, Queensland Government, Brisbane, January 2014.

[4] Cook, P.J. (2013). Life cycle of coal seam gas projects: Technologies and potential impacts. Report for the New South Wales Office of the Chief Scientist and Engineer, Sydney, June 2013.

[5] Sydney Catchment Authority (2012). Literature review: Coal seam gas impacts on water resources. Sydney Catchment Authority, New South Wales Government, Penrith, New South Wales, December 2012.

[6] Khan, S. and Kordek, G. (2013). Coal seam gas: Produced water and solids. Prepared for the New South Wales Office of the Chief Scientist and Engineer, School of Civil Environmental Engineering, The University of New South Wales, Sydney, June 2013.

[7] Cubby, B. (2010). Origin stops coal seam gas drilling after chemicals found in water. The Sydney Morning Herald, October 21, 2010.

[8] Lloyd-Smith, M. and Senjen, R. (2011). Hydraulic fracturing in coal seam gas mining: The risks to our health, communities, environment and climate. National Toxics Network, Bangalow, NSW, July 2011.

[9] Commonwealth Scientific and Industrial Research Organisation (2012). Coal seam gas: Produced water and site management. Commonwealth Scientific and Industrial Research Organisation (CSIRO), Clayton South, Victoria.

[10] Egan G (2012). CSG waste water trucked to Ipswich. The Queensland Times, June 13, 2012.

[11] Department of Environment and Heritage Protection (2012). CSG/LNG compliance plan 2012-2013. Energy Resources and Enforcement Branch of the Environmental Services and Regulation Division, Department of Environment and Heritage Protection, State Government of Queensland, Brisbane, November 2012.

[12] Glynn, P. (2009). Treatment options for water produced by CSG extraction, Gas Today, November 2009.

[13] Murray R.S., and Grant, C.D. (2007). The impact of irrigation on soil structure. School of Earth \& Environmental Sciences, The University of Adelaide, National Program for Sustainable Irrigation (Land \& Water Australia), July 2007.
[14] Fergusson, L. (2009). Commercialisation of environmental technologies derived from alumina refinery residues: A ten-year case history of Virotec. Commonwealth Scientific and Industrial Research Organisation (CSIRO), Project ATF-06-3 "Management of Bauxite Residues", Department of Resources, Energy and Tourism (DRET), Commonwealth Government of Australia, Asia-Pacific Partnership on Clean Development and Climate, Canberra.

[15] Fergusson, L. (2012). ViroMine technology: A solution to the world's mining megawaste, Prana World Publishing, Gold Coast, Australia, 170pp.

[16] Fergusson, L. (2007). The conversion and sustainable use of alumina refinery residues: Global solution examples, in Light Metals 2007, edited by T.J. Galloway, The Minerals, Metals \& Materials Society, 2007, pp. 105-112.

[17] Taylor, K., Mullett, M., Adamson, H., Wehrli, J. and Fergusson, L. (2011). Application of nanofiltration technology to improve sea water neutralization of Bayer process residue, in Light Metals 2011, edited by Stephen J. Lindsay, John Wiley \& Sons, Inc., Hoboken, New York, 2011, 79-87.

[18] Fergusson, L. (2010). Virotec: A ten-year story of success in environmental remediation, Prana World Publishing, Gold Coast, Australia, 189pp.

[19] Clark, M.W., McConchie, D., Berry, J., Caldicott, W., Davies-McConchie, F., and Castro, J. (2004). Bauxsol technology to treat acid and metals: Applications in the coal industry. In J. Skousen and T. Hilton (Eds.), proceedings of the Joint Conference of the American Society of Mining and Reclamation and the 25th West Virginia Surface Mine Drainage Task Force, Morgantown, West Virginia, April 18-24, 2004, 292-313.

[20] Fergusson, L. (2013). An industrial legacy now gone, Water Management and Environment, 24(1), 40.

[21] McConchie, D., Clark, M., Maddocks, G., Davies-McConchie, F., Pope, S., and Caldicott, W. (2003). The use of Bauxsol technology in mine site management and remediation. In proceedings of the CIM Mining Industry Conference, Montreal, May 2003, Disk Record s33a1141, 20pp.

[22] Environment Protection Authority (2009). Industrial waste resource guidelines: Soil hazard categorisation and management. Environment Protection Authority, Victorian Government, Melbourne, 2009.

[23] National Environment Protection Council (2013). National environment protection (assessment of site contamination) amendment measure 2013, National Environment Protection Council, Canberra.

[24] Department of Natural Resources Queensland (1997). Salinity management handbook. Department of Natural Resources, Brisbane, Queensland, 1997.

[25] Wagner, R. (1987). Dryland salinity in the south-east region. Soil Conservation Service of NSW, Sydney, NSW. 